\title{
Effect of Integrated Nutrient Management on Growth, Yield, Quality and Nutrient Content of Khasi Mandarin (Citrus reticulata) in Acidic Soil of Assam, India
}

\author{
Arunima Gogoi ${ }^{*}$, A.C. Barbora ${ }^{1}$, R. K. Kakoti ${ }^{1}$, D. Bhattacharya ${ }^{2}$, \\ S. Dutta ${ }^{2}$, B. Medhi ${ }^{2}$ and J. Saikia ${ }^{1}$ \\ ${ }^{1}$ Citrus Research Station, Assam Agricultural University, Tinsukia, Assam, India \\ ${ }^{2}$ Department of Soil Science, Assam Agricultural University, Assam, India \\ *Corresponding author
}

\begin{tabular}{|c|}
\hline Keywords \\
\hline $\begin{array}{l}\text { INM, Khasi } \\
\text { mandarin, } \\
\text { Recommended } \\
\text { doses of fertiliser }\end{array}$ \\
\hline Article Info \\
\hline $\begin{array}{l}\text { Accepted: } \\
12 \text { August } 2018 \\
\text { Available Online: } \\
\text { 10 September } 2018\end{array}$ \\
\hline
\end{tabular}

\section{A B S T R A C T}

The experiment was carried out in twelve years old Khasi mandarin plot in Tinsukia district of Assam, India during 2005-2015 to find out the effect of integrated nutrient management (INM) on yield, quality and nutrient content of Khasi mandarin (Citrus reticulata) in acidic soil of Assam. The experiment was laid out with $5 \mathrm{~m} \times 5 \mathrm{~m}$ spacing along with 5 treatments, 4 replication and designed with RBD. Existing technology for application of nutrients in Khasi mandarin is split application of the recommended doses of $\mathrm{N}, \mathrm{P}_{2} \mathrm{O}_{5}$ and $\mathrm{K}_{2} \mathrm{O}$ i.e., 600:300:600 g N, $\mathrm{P}_{2} \mathrm{O}_{5}$ and $\mathrm{K}_{2} \mathrm{O} / \mathrm{pl} / \mathrm{yr}$ along with $7.5 \mathrm{~kg}$ mustard oil cake/pl/yr in two splits. The result revealed that application of 75\% RDF + VAM (500 $\mathrm{g} /$ plant $)+$ PSB (100 g/plant $)+$ Azospirillum, $(100 \mathrm{~g} / \mathrm{plant})+T$. harzianum (100 g/plant) were found effective in improving the yield, soil nutrient status and quality of Khasi mandarin with B:C ratio (4.75). The fruit obtained under this treatment was found significantly superior in quality as evident from highest juice content i.e. $48.95 \%$; TSS i.e. 13.77\%; Ascorbic acid i.e. $48.93 \%$; total sugar, i.e. $7.47 \%$ and lowest acidity, i.e. $0.37 \%$. The time taken for maturity was the lowest (244 days) while shelf life was the highest (18 days) though not significant. Significantly higher soil fertility status and superior N, P, K content on leaf were observed under this treatment.

\section{Introduction}

Khasi Mandarin is the most important citrus fruit cultivated in India. The Khasi mandarin (Citrus reticulata), commonly known as Orange, produced in this region is famous in India for its superior quality in respect of its flavour, Juice content, soluble sugar and acidity ratio. The soil and climatic conditions of this region are most suitable for its production \& it has the potentiality to generate livelihood in the rural areas substantially. Citrus is one of the largest fruit industries in the world having nutraceutical properties. In India, citrus holds a prominent place among the major commercial fruits covering an area of about 985 thousands ha with an annual production of 11,419 thousands metric tonnes and productivity of 11.59 t/ha (National Horticulture Board, 2016-17). 
Among the Citrus fruits, Khasi mandarin covering an area 17.55 thousand ha, and production 236.01 thousands metric tons in Assam and an area of 117.89 thousand ha with 672.78 thousands metric tons Production in N E India (Horticultural Statistics at a glance, 2017,) whereas Khasi mandarin occupies 1.77 thousand ha area, 27.97 thousands metric tons production in Tinsukia with highest productivity of 15.8 tons/ha (Horticultural Statistics at a glance, 2017)

Application of $\mathrm{N}, \mathrm{P}$ and $\mathrm{K}$ through inorganic fertilizers can enhance the growth and yield to considerable. Biofertilizers provide a variety of plant nutrients and improve soil structure by providing binding effect to soil aggregates. It increases cation exchange capacity of the soil, water holding capacity and phosphate availability. The fertilizer use efficiency and microbial quality of the soil is also improved through Biofertilizers. It is rich in organic matter and can be supplemented with NPK fertilizers. Biofertilizers plays an important role in increasing availability of nutrients and productivity in sustainable manner. Azospirillum is free living bacteria which may add $25-30 \mathrm{~kg} \mathrm{~N}$ ha-1 year-1 in a field of nonlegume crop under favourable condition and also secrets some growth promoting substances. Application of PSB increases nodulation, crop growth, nitrogenase activity, nutrient uptake and crop yield.

Indiscriminate use of fertilizers and other agrochemicals has resulted in the depletion of beneficial micro-organism from the soil and has caused infertile and unproductive soil. In this respect biofertilizers play multifaceted role by not only enriching the soil microorganism but also as nutrients, stabilizers, hormones and insulators (Bihari et al., 2009). The advantages of integrated nutrients management generally superior over use of each component separately. Integration of chemical fertilizers with organic manures and biofertilizers had maintained long term fertility and sustains higher productivity (Pillai et al., 1985).

The nutritional requirement of Khasi mandarin varied widely owing to its perennial in nature (Bhargava, 2002). Mandarins, being a commercially important fruit crop, proper and correct dose of organic, inclusive of biofertilizers in an integrated way with inorganic fertilizers need to be evaluated to ensure high economic productivity and sustaining the nutrition of the plant at a desirable level. Moreover, the quantification of most of the bio-fertilizers to substitute an unit quantity of chemical fertilizer are yet to be established in most of the fruit crops. Keeping all these aspects in view, the present study aims to find an economically viable INM practice in Khasi mandarin based on nutrient content of plant as well as in the soil and also find out the effect of INM on yield, quality and nutrient content of citrus.

\section{Materials and Methods}

The present investigation was carried out on twelve years old Mandarin orange (Citrus reticulata Blanco.) of uniform growth and vigour in Barekuri areas of Tinsukia district of Assam in India during 2005 to 2015 with five different treatments viz., T1 : Recommended dose of NPK-RDF (Control), T2 = RDF + VAM (500 g/plant) + PSB (100 g/plant) + Azospirillum (50 g/plant), T3 $=100 \% \mathrm{RDF}+$ VAM (500 g/plant) + PSB (100 g/plant) + Azospirillum (100 g/plant) $+T$. harzianum $(100 \mathrm{~g} / \mathrm{plant}), \mathrm{T} 4=75 \% \mathrm{RDF}+\mathrm{VAM}(500$ $\mathrm{g} /$ plant $)+$ PSB (100 g/plant) + Azospirillum (100 g/plant) $+T$. harzianum (100 g/plant) and $\mathrm{T} 5=50 \% \mathrm{RDF}+\mathrm{VAM}$ (500 g/plant $)+\mathrm{PSB}-$ $(100 \mathrm{~g} /$ plant $)+$ Azospirillum $(100 \mathrm{~g} /$ plant $)+T$. harzianum (100 g/plant).

The treatments were applied in randomized block design with four replications having 
four plants each. The sources of $\mathrm{N}, \mathrm{P}_{2} \mathrm{O}_{5}$ and $\mathrm{K}_{2} \mathrm{O}$ were urea, rock phosphate and muriate of potash, respectively. All the inorganic components with rock phosphate and MOC except bio-fertilizers were applied in two equal split doses during March and September. Biofertilizers were applied as single dose with required quantities of mustard oil cake (MOC) during the month of March. Soil physico-chemical properties over the years were determined as per the method outlined by Jackson, 1979. Number of fruits and other quality parameters were estimated by adopting the standard techniques. Leaf samples were collected following the technique of Kohli et al., (1998) for determination of total $\mathrm{N}, \mathrm{P}$ and $\mathrm{K}$ contents. Benefit: Cost ratio was determined after pooling the data over the years of experiment. The data generated in three consecutive years viz. 2005 to 2015 were pooled and used to prepare analysis of variance table and accordingly C.D. was computed as described by Panse and Sukhtame (1954).

\section{Results and Discussion}

\section{Soil characteristics}

Initial soil characteristics (Table 1) showed that soils were acidic in nature $(\mathrm{pH} \mathrm{4.7)}$ and high organic carbon contents. Initial available $\mathrm{N}, \mathrm{P}_{2} \mathrm{O}_{5}$ and $\mathrm{K}_{2} \mathrm{O}$ content in soils were found to be low.

After application of treatments higher organic carbon contents and maximum available $\mathrm{N}$, $\mathrm{P}_{2} \mathrm{O}_{5}$ and $\mathrm{K}_{2} \mathrm{O}$ content in soils were observed in $\mathrm{T} 4$ treatment involving application of $75 \%$ RDF + VAM (500 g/plant) + PSB (100 $\mathrm{g} /$ plant $)+$ Azospirillum, (100 g/plant) $+T$. harzianum (100 g/plant) followed by $\mathrm{T} 3$ treatment with having 100\% RDF + VAM (500 g/plant) + PSB (100 g/plant) + Azospirillum $(100 \mathrm{~g} /$ plant $)+T$. harzianum $(100 \mathrm{~g} /$ plant $)$. Statistical analysis revealed that significant differences was found in soil parameters i.e organic carbon content, available $\mathrm{N}, \mathrm{P}_{2} \mathrm{O}_{5}$ and $\mathrm{K}_{2} \mathrm{O}$ content in soil with having critical difference $\mathrm{CD}$ at $5 \%$ i.e., $0.11 ; 18.9 ; 5.4 ; 7.8$ respectively.

\section{Leaf nutrient content}

After application of treatments Leaf nutrient content were observed at flowering (F) and harvesting $(\mathrm{H})$ of Khasi mandarin. Leaf nutrient content of $\mathrm{N}, \mathrm{P}$ and $\mathrm{K}$ were found maximum in $\mathrm{T} 4$ treatment both flowering $(\mathrm{F})$ and harvesting $(\mathrm{H})$ of Khasi mandarin (Table 2). Significant differences (CD at $5 \%$ ) were observed in Leaf nutrient content of $\mathrm{N}, \mathrm{P}$ and K.

\section{Growth}

Maximum plant height $(6.46 \mathrm{~m})$ and canopy volume $\left(45.62 \mathrm{~m}^{3}\right)$ was observed under the treatment (T4) involving with $75 \%$ recommended dose of NPK (of $450 \mathrm{~g} \mathrm{~N}, 225 \mathrm{~g}$ $\mathrm{P}_{2} \mathrm{O}_{5}, 450 \mathrm{~g} \mathrm{~K}_{2} \mathrm{O}$ and $5.625 \mathrm{~kg}$ Neem Oil Cake) + VAM (500 g/plant) + PSB (100 g/plant) + Azospirillum, $(100 \mathrm{~g} / \mathrm{plant})+T$. harzianum (100 g/plant) (Table 3). This could be explained by the activities of the biofertilizers viz. nitrogen fixation, release and solubilize the Pi from insoluble phosphate, mobilize the phosphate, production of phytohormones etc. with simultaneous uptake of nutrients. Increase cell elongation and cell multiplication due to enhanced nutrient uptake following application of Azospirillum and PSB might have caused plant height (Preethi et al., 1999). Growth Beside this application of $75 \%$ recommended dose of NPK along with Azospirillum might increase the nitrogen content. Nitrogen is a constituent of protein which helps in division and enlargement of cell, thereby, enhancing plant growth. The above results are in accordance with the finding of Chandha et al., (1999) and Acharya and Dashora (2004). 
Table.1 Effect of bio-fertilizers on soil fertility status

\begin{tabular}{|c|c|c|c|c|c|}
\hline \multirow{2}{*}{ Treatments } & \multicolumn{3}{|c|}{ Soil Properties } \\
& $\mathrm{pH}$ & $\mathrm{OC} \%$ & $\mathrm{Av} . \mathrm{N}$ & $\mathrm{Av} \cdot \mathrm{P}_{2} \mathrm{O}_{5}$ & $\mathrm{Av} . \mathrm{K}_{2} \mathrm{O}$ \\
\hline $\mathrm{T}_{1}$ & 4.7 & 1.09 & 298 & 26.9 & 132.5 \\
\hline $\mathrm{T}_{2}$ & 4.9 & 1.13 & 318 & 28.6 & 158.4 \\
\hline $\mathrm{T}_{3}$ & 5.1 & 1.28 & 327 & 32.8 & 155.1 \\
\hline $\mathrm{T}_{4}$ & 5.4 & 1.41 & 360 & 33.9 & 175.3 \\
\hline $\mathrm{T}_{5}$ & 5.0 & 1.28 & 302 & 24.3 & 134.2 \\
\hline Initial & $\mathbf{4 . 7}$ & $\mathbf{0 . 9 5}$ & $\mathbf{2 3 4}$ & $\mathbf{1 9 . 0 5}$ & $\mathbf{1 3 1 . 9}$ \\
\hline CD at 5\% & $\mathrm{NS}$ & 0.11 & 18.9 & 5.4 & 7.8 \\
\hline
\end{tabular}

Table.2 Effect of bio-fertilizers on leaf N, P and $\mathrm{K}$ at flowering $(\mathrm{F})$ and harvest $(\mathrm{H})$ of mandarin

\begin{tabular}{|c|c|c|c|c|c|c|}
\hline \multirow[t]{3}{*}{ Treatments } & \multicolumn{6}{|c|}{ Leaf nutrient concentration (\%) } \\
\hline & \multicolumn{2}{|c|}{$\mathrm{N}$} & \multicolumn{2}{|c|}{$\mathrm{P}$} & \multicolumn{2}{|c|}{$\mathbf{K}$} \\
\hline & $\mathrm{F}$ & $\mathrm{H}$ & $\mathrm{F}$ & & $\mathrm{F}$ & $\bar{H}$ \\
\hline$\overline{T_{1}}$ & 2.48 & 2.24 & 0.19 & 0.16 & 1.21 & 1.17 \\
\hline $\mathrm{T}_{2}$ & 2.40 & 2.26 & 0.29 & 0.22 & 1.26 & 1.20 \\
\hline$T_{3}$ & 2.67 & 2.51 & 0.28 & 0.27 & 1.38 & 1.32 \\
\hline $\mathrm{T}_{4}$ & 2.94 & 2.64 & 0.31 & 0.30 & 1.56 & 1.49 \\
\hline$\overline{T_{5}}$ & 2.50 & 1.99 & 0.23 & 0.17 & 1.12 & 1.07 \\
\hline CD at $5 \%$ & 0.40 & 0.25 & 0.08 & 0.17 & 1.18 & 1.14 \\
\hline
\end{tabular}

Table.3 Effect of bio-fertilizers on quality attributes of mandarin

\begin{tabular}{|c|c|c|c|c|c|c|c|c|c|}
\hline Treatments & $\begin{array}{c}\text { Plant } \\
\text { height } \\
(\mathrm{m})\end{array}$ & $\begin{array}{c}\text { Canopy } \\
\text { volume } \\
\left(\mathrm{m}^{3}\right)\end{array}$ & $\begin{array}{c}\text { Fruit } \\
\text { yield } \\
(\mathrm{t} / \mathrm{ha})\end{array}$ & $\begin{array}{c}\text { Juice } \\
(\%)\end{array}$ & $\begin{array}{c}\text { Acidity } \\
(\%)\end{array}$ & $\begin{array}{c}\text { TSS } \\
\left({ }^{\circ} \mathrm{Brix}\right)\end{array}$ & $\begin{array}{c}\text { Ascorbic } \\
\text { acid } \\
(\mathrm{mg} / 100 \mathrm{ml})\end{array}$ & $\begin{array}{c}\text { TSS/A } \\
\text { cid } \\
\text { ratio }\end{array}$ & $\begin{array}{c}\text { Shelf } \\
\text { life } \\
(\text { days })\end{array}$ \\
\hline $\mathrm{T}_{1}$ & 6.27 & 38.02 & 32.34 & 43.02 & 0.46 & 10.60 & 43.43 & 23.04 & 14 \\
\hline $\mathrm{T}_{2}$ & 6.28 & 38.27 & 29.58 & 43.33 & 0.45 & 11.43 & 45.83 & 25.4 & 15 \\
\hline $\mathrm{T}_{3}$ & 6.31 & 44.78 & 32.63 & 46.58 & 0.42 & 11.60 & 46.23 & 27.61 & 17 \\
\hline $\mathrm{T}_{4}$ & 6.46 & 45.62 & 39.60 & 48.95 & 0.37 & 13.77 & 48.93 & 37.21 & 18 \\
\hline $\mathrm{T}_{5}$ & 6.11 & 40.15 & 30.55 & 41.01 & 0.45 & 10.25 & 45.88 & 22.77 & 16 \\
\hline $\mathrm{CD}$ at $5 \%$ & 0.23 & 5.81 & 2.79 & 6.34 & $\mathrm{NS}$ & 1.98 & 2.89 & 9.08 & $\mathrm{NS}$ \\
\hline
\end{tabular}

Table.4 B: C ratio

\begin{tabular}{|c|c|}
\hline Treatment & B:C ratio \\
\hline $\mathbf{T}_{\mathbf{1}}$ & 3.08 \\
\hline $\mathbf{T}_{\mathbf{2}}$ & 3.24 \\
\hline $\mathbf{T}_{\mathbf{3}}$ & 4.05 \\
\hline $\mathbf{T}_{\mathbf{4}}$ & 4.75 \\
\hline $\mathbf{T}_{\mathbf{5}}$ & 2.89 \\
\hline
\end{tabular}




\section{Yield}

The higher yield (39.60 t/ha) was found in T4 treatment followed by T3 treatment (Table 3). Statistical analysis revealed that significant differences ( $\mathrm{CD}$ at $5 \%$ i.e., 2.79) were observed in yield of Khasi mandarin. Improved yield might be due to application of biofertilizers as a result of availability of major and minor nutrients at all the essential stages of growth and development \& improvement of physio-chemical properties of soil; increase in enzymatic activity, microbial population and also increase in plant growth hormones and it also helps to increase the biological nitrogen fixation, and availability of phosphorus which is required for strong vegetative growth \& upon decomposition-release nitrogen and phosphorus contents and allele-chemicals leading to disease suppression.

\section{Quality attributes of mandarin}

The fruit obtained under the treatment $\mathrm{T}_{4}$, having $75 \%$ recommended dose of NPK (of $450 \mathrm{~g} \mathrm{~N}, 225 \mathrm{~g} \mathrm{P}_{2} \mathrm{O}_{5}, 450 \mathrm{~g} \mathrm{~K}_{2} \mathrm{O}$ and $5.625 \mathrm{~kg}$ Neem Oil Cake) + VAM (500 g/plant $)+$ PSB $(100 \mathrm{~g} /$ plant $)+$ Azospirillum,$(100 \mathrm{~g} /$ plant $)+$ T. harzianum (100 g/plant) was also found significantly superior in quality as evident from highest juice content, 48.95\%; TSS, 13.77\%; Ascorbic acid, 48.93\%; total sugar, $7.47 \%$ and lowest acidity, $0.37 \%$ (Table 3 ). The time taken for maturity was the lowest (244 days) while shelf life was the highest (18 days) though not significant. Such an increase in total sugars, TSS and juice percentage might be due to synergistic effect of nitrogen from Azospirillum and potassium from PSB. The synergistic effect by using of these nutrients as well as other in the sugar metabolism of strawberry fruits were also reported by El-Hamid et al., 2006. Maximum B: C ratio (4.7) was also observed under this treatment $\left(\mathrm{T}_{4}\right)$.
The treatment involving application of $75 \%$ RDF + VAM (500 g/plant) + PSB (100 g/plant $)+$ Azospirillum, (100 g/plant $)+T$. harzianum (100 g/plant) was found to be effective in improving the yield and quality of mandarin compared to the rest of the treatments including application of recommended doses of fertilizer control. The maximum B: C ratio (4.75) was found under this treatment (Table 4).

\section{Acknowledgement}

The authors acknowledge the receipt of all kind of help and support rendered by Assam Agricultural University and the AICRP on Fruits for regular and time-to-time suggestion in making the assignment successful.

\section{References}

Acharya, M. M. and Dashora, L. K., 2004. Response of graded levels of Nitrogen and Phosphorus on vegetative growth and flowering in African marigold (Tegets erecta L.). Journal of Ornamental Horticulture, 7 (2):179183.

Ahmed, F. F. et al., (1988). Annals Agric. Sci. (Cairo), 33: 1249-1298.

Bhargava, B. S. (2002). J. Indian Soc. Soil Sci. 50: 352-373.

Bihari, M., Narayan, S. and Singh, A.K., 2009. Effect of pruning levels and biofertilizers on production of Rose cut flowers. Journal of Ornamental Horticulture, 12(1): 48-53.

Chandha, A. P.S., Rathore, S.V.S. And Ganesh, R. K., 1999. Influence of Nitrogen and Phosphorus and ascorbic acid on yield and flowering of African marigold cv. Double giant. Journal of South Indian Horticulture, 47 (1-6): 342-344.

Chonkar, P. K. (2002). J. Indian Soc. Soil Sci. 80: 328-332.Vol. 41, No. 4, 2007241 
Du Plessis, S. F. \& Koen, T. J. (1988). Proc. International Soc. Citriculture. 2: 663 672.

El-Hamid, Aza AS, Abbou AA, Mansour SAA, El-Sayed AAA. Effect of some biofertilizers on yield and fruit quality of strawberry. Ann Agr Sci. 2006; 44(10):251-64.

Horticultural Statistics at a glance, 2017. Government of India, Ministry of Agriculture and Farmers welfare, Department of Agriculture, Cooperation and Farmers Welfare. Horticulture Statistics Division

Jackson, M. L. (1979). Soil Chemical Analysis. Prentice Hall of India Pvt. Ltd., New Delhi.

Kohli, R. R. et al., (1998). Trop. Agric. Res. Ext., Sri Lanka 1: 5-15.
National Horticulture Board, 2016-17. Ministry of Agriculture, Government of India

Panse, V. G. and Sukhatme, P. V. (1954). Statistical Methods for Agriculture Workers. Indian Coun. Agric. Res., New Delhi.

Pillail, K.G., Devi, S.I., and Setty, T.K.D., 1985. Research achievement of All India Co-ordinated Agro-nomical Research Project Fertilizer News, 30: 26-34.

Preethi, T. L., Pappiah, C. M. and Anbu, S., 1999. Studies on the effect of Azospirillum sp., Nitrogen and Ascorbic acid on growth and flowering of Edward Rose (Rosa bourbonians). Journal of South Indian Horticulture, 47 (1-6): 106-110.

\section{How to cite this article:}

Arunima Gogoi, A.C. Barbora, R.K. Kakoti, D. Bhattacharya, S. Dutta, B. Medhi and Saikia, J. 2018. Effect of Integrated Nutrient Management on Growth, Yield, Quality and Nutrient Content of Khasi Mandarin (Citrus reticulata) in Acidic Soil of Assam, India. Int.J.Curr.Microbiol.App.Sci. 7(09): 1675-1680. doi: https://doi.org/10.20546/ijcmas.2018.709.202 